\title{
Implementasi Metode Finite State Machine Pada Permainan Tradisional Setatak Berbasis Android
}

\author{
Agustin $^{* 1}$, Aldino Evel ${ }^{2}$, Susanti ${ }^{3}$, Rahmaddeni ${ }^{4}$ \\ ${ }^{1,2}$ STMIK Amik Riau; Jl. Purwodadi KM 10 Panam Pekanbaru \\ ${ }^{3}$ Jurusan Teknologi Informasi, Teknik Informatika \\ e-mail:*¹agustin@sar.ac.id, ${ }^{2}$ aldinoevel@gmail.com, ${ }^{3}$ susanti@ stmik-amik-riau.ac.id, \\ ${ }^{4}$ rahmaddeni@stmik-amik-riau.ac.id
}

\begin{abstract}
Abstrak
Perkembangan dunia game sekarang ini, lebih cenderung pada permainan bersifat game mobile. Masih sedikit game yang memperkenalkan permainan tradisional kepada generasi muda terutama pada anak-anak sehingga kurangnya pengetahuan anak-anak tentang permainan tradisional contohnya permainan setatak. Setatak merupakan permainan tradisional lompat-lompatan pada kotak-kotak yang digambar di atas tanah, kemudian melompat dengan satu kaki dari kotak satu ke kotak berikutnya. Seiring dengan kemajuan teknologi, untuk menjaga dan melestarikan permainan tradisional setatak, permainan tradisional setatak dibuat berbasis android dalam bentuk 2D. Metode yang digunakan adalah metode Finite State Machine (FSM). Metode Finite State Machine (FSM), merupakan perancangan sistem kontrol yang menggambarkan tingkah laku atau prinsip kerja sistem dengan menggunakan tiga hal: State (Keadaan), Event (kejadian) dan action (aksi). Penerapan metode FSM pada game ini adalah untuk mengatur perilaku sistem, yaitu perpindahan kaki pemain dari satu petak ke petak yang lainnya selama game berlangsung. Dengan adanya aplikasi game setatak ini anak-anak dapat memahami dan mampu memainkan permainan game setatak. Hasil pengujian menunjukkan bahwa game setatak dapat dimainkan, disukai dan diminati oleh anak-anak serta menambah pengetahuan anak-anak tentang permainan tradisional setatak.
\end{abstract}

Kata kunci_Finite State Machine, Permainan Tradisional, Setatak, Android

\begin{abstract}
The growth of the game trend today tends to be mobile games.There are still a few games that introduce traditional games to the younger generation, especially for children, so there is a lack of children's knowledge about traditional games, for example, Setatak game. Setatak is a traditional game played by jumping over a box drawn on a flat surface on the ground, jumping from one box to another using only one leg. Along with advances in technology, in order to maintain and preserve traditional games, traditional games are made based on Android in 2D. The method used is the Finite State Machine (FSM) method. Finite State Machine (FSM) method, which is a control system design that describes the behavior or working principles of the system using the following three things: State, Event and action. The application of the FSM method in this game is to regulate the behavior of the system, namely the movement of the player's feet from one box to another during the game. With the existence of this game application, children can understand and be able to play game games as well. The test results show that the game can be played, liked and interested by children as well as increase children's knowledge about traditional games setatak.
\end{abstract}

Keywords — Finite State Machine, Traditional Games, Setatak, Android 


\section{PENDAHULUAN}

$\mathrm{C}^{\mathrm{s}}$ epat serta pesatnya perkembangan teknologi memberi peluang pada berbagai permainan tradisional untuk dapat disimulasikan dalam bentuk game, karena dari perkembangan teknologi tersebut telah tercipta berbagai aplikasi yang mampu mensimulasikan permainan-permainan tradisional dalam bentuk game pada smartphone. Permainan tradisional merupakan bagian dari aneka ragam kebudayaan yang ada di Indonesia. Sebelum adanya perkembangan teknologi muncul ditengah-tengah masyarakat, berbagai permainan tradisional telah mewarnai kehidupan anak- anak Indonesia. [1]

Game merupakan sebuah hiburan berbentuk multimedia, menggunakan media elektornik yang dibuat semenarik mungkin. Tujuannya agar pemain bisa mendapatkan sesuatu sehingga mendatangkan kepuasan batin. Bermain game juga bisa dijadikan sebagai sarana pembelajaran. Game menjadi bagian dari media teknologi sebagai media hiburan yang populer di kalangan masyarakat mulai anak kecil sampai orang dewasa. Beragam jenis game, ada yang berjenis Adventure, Fighting, Simulasi, Real-Time Strategy (RTS), Role-Playing Game (RPG), First Person Shooter (FPS), dan masih banyak lagi jenis yang lainnya. [2]. Banyaknya game yang ada sekarang, namun lebih cenderung pada permainan bersifat game mobile, hanya sedikit yang membahas atau membuat game tentang permainan tradisional, sehingga permainan tradisional sering dilupakan oleh anak-anak pada masa kini, contohnya game statak.

Setatak merupakan permainan anak-anak yang masih berkembang di Riau dan sekitarnya. Permainan ini tergolong kedalam permainan hiburan yang dilakukan saat waktu senggang oleh anak laki-laki dan perempuan yang berjumlah 2 sampai 4 orang dengan usia 6 sampai 12 tahun. [1]. Cara memainkan setatak yaitu, pertama semua pemain melakukan suit atau hompimpa, yang menang berhak melakukan permaian terlebih dahulu. Pemain yang menang hompimpa ada pemain pertama. Pemain pertama melemparkan gacuk (yang biasanya berupa pecahan genting/kreweng, keramik lantai, ataupun batu yang datar) ke kotak nomor satu.

Pemain pertama melompat dengan satu kaki dari kotak pertama sampai ke kotak berikutnya, kemudian kembali lagi dengan mengambil gacuk yang ada di kotak pertama dengan posisi kaki satu masih diangkat atau tidak menyentuh tanah. Petak yang ada gacuk, baik milik sendiri maupun milik lawan, tak boleh diinjak, petak tersebut harus dilompati, atau dilangkahi saja. Sehabis satu ronde, atau putaran permainan, pemain mengambil "bintang". Petak yang sudah diberi tanda bintang, boleh diinjak dua kaki bagi yang memilikinya, tapi tidak boleh diinjak oleh pihak lawan [3].

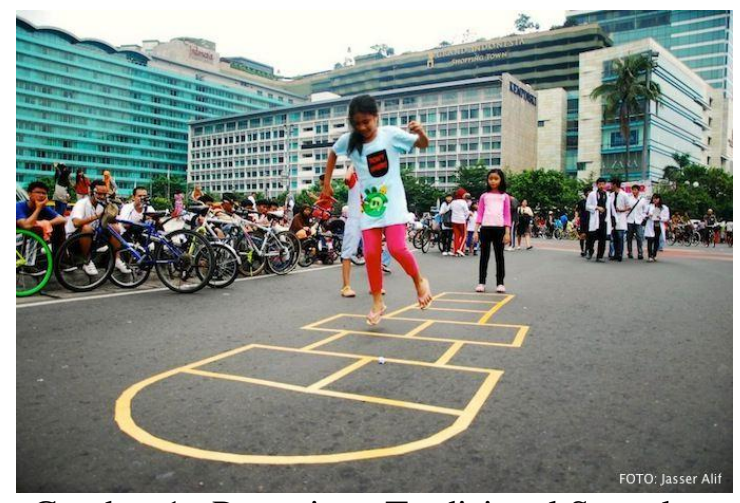

Gambar 1. Permainan Tradisional Setatak

Bentuk usaha menjaga dan melestarikan permainan tradisional setatak, dibuatlah aplikasi permainan tradisional setatak berbasis android dalam bentuk 2D. Metode yang digunakan adalah metode Finite State Machine (FSM). Metode ini merupakan sistem kontrol yang menggambarkan tingkah laku atau prinsip kerja sistem dengan menggunakan tiga hal, yaitu: 
state (keadaan), events (kejadian) dan action (aksi) [4]. Tujuan dari penelitian ini yaitu membangun aplikasi permainan tradisional setatak menggunakan metode Finite State Machines berbasiskan android, agar anak-anak mampu memahami dan mampu memainkan game setatak dengan melalui smartphone kapan saja dan dimanapun berada.

Beberapa penelitian yang telah dilakukan oleh peneliti sebelumnya terkait dengan penelitian ini yaitu penelitian dilakukan oleh Fadel Marzian dan Mukti Qamal pada tahun 2017 yang membuat sebuah game RPG bertemakan kerajaan, dimana misi dan tujuan yang harus dicapai dalam game yaitu mengembalikan pedang kerajaan yang hilang. Game ini berbasis desktop, menggunakan aplikasi Game Maker Studio 1.4 dan bahasa pemograman Game Maker Language (GML)[5]. Penelitian lainnya dilakukan oleh Anugraha et al pada tahun 2018 yang membahas tentang game edukasi berbasis kinect untuk anak autis atau anak berkebutuhan khusus menggunakan metode FSM. Game ini berhasil membantu anak berkebutuhan khusus atau autis untuk mengenal benda di dalam rumah[6]. Penelitian berikutnya dilakukan oleh Hormansyah et al pada tahun 2018 yang mengimplementasi pada Game Perjuangan Pangeran Diponegoro. Hasilnya metode FSM dapat menentukan perilaku Non Character Player (NPC), sehingga metode FSM dapat memberikan pengaruh terhadap aksi pengguna ke sistem.[2]

Penelitian berikutnya yakni pada tahun 2019, dilakukan oleh Ramadhan et al yang membuat game edukasi tentang pengenalan budaya dan wisata Kalimantan Barat. Game yang diberi nama "Borneo Adventure" berisi tiga mini game yaitu pertanyaan, tebak gambar dan puzzle. Penggunaan metode Finite State Machine terdapat pada mini game yang selalu menawarkan pilihan bermain game atau melanjutkan ke kota berikutnya sepanjang game masih berjalan. Pengujian dilakukan terhadap pengguna game menghasilkan nilai 83,1 \% sehingga masuk kategori layak sebagai media pengenalan wisata dan budaya Kalimantan Barat [7]. Masih pada tahun yang sama yakni tahun 2019, Hidayat et al membuat game berbasis Augmented Reality (AR) yang menerapkan FSM untuk mengatur pergerakan Non Player Character (NPC). Metode tersebut digunakan sebagai strategi dalam menentukan action animation prediction. Penelitian ini berhasil membuat battle game dengan pendekatan metode versi Luther. Berdasarkan pengujian, dari hasil pengujian alpha secara fungsional sudah sesuai dan dari pengujian beta yaitu User Acceptance Test (UAT) didapat nilai sebesar $71 \%$ yang berarti game yang dibangun dinyatakan layak untuk digunakan dengan interpretasi baik.[8]

\section{METODE PENELITIAN}

Mempermudah dalam penyelesaian penelitian, maka dibuatlah kerangka kerja yang menggambarkan tahapan penelitian, terlihat pada gambar 2 berikut:

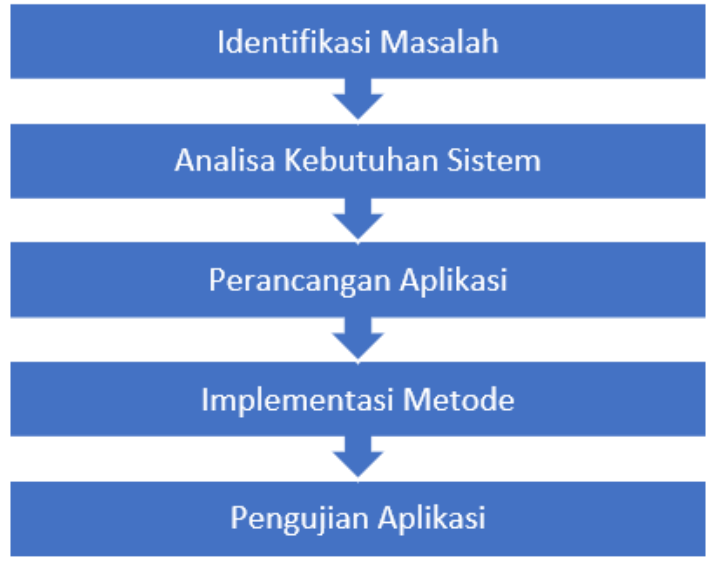

Gambar 2. Tahapan Penelitian 
Gambar 2. Diatas Menerangkan Bahwa Penelitian Ini Dilakukan Dalam Lima Tahapan, yaitu:

1. Identifikasi Masalah

Pada tahap ini dilakukan pencarian masalah yang ada untuk mendapatkan solusi yang diinginkan. Ada beberapa jenis permainan daerah yang jarang dimainkan, diantaranya adalah permainan setatak, pletokan, balap karung, dan permainan lainnya. Setiap permainan tersebut memiliki aturan dan cara bermain. Beberapa dearah Riau sudah jarang memainkan seperti permainan setatak, perlu adanya game untuk meningkatkan minat generasi muda dan anak-anak terhadap permainan daerah tersebut. Berdasarkan analisa masalah maka dapat disimpulkan pada penelitian ini bagaimana aplikasi game berbasis android setatak dibuat dengan karakter-karakter pemain yang menarik, serta terdapat beberapa pilihan menu player dan 4 pilihan model setatak yaitu, model setatak pesawat, setatak rok, setatak gunung, dan setatak buaya, dengan menggunakan konsep FSM

2. Analisis Kebutuhan Sistem

Analisis kebutuhan dilakukan untuk mengetahui rincian kebutuhan sistem. Rincian kebutuhan sistem meliputi analisis perangkat lunak (Software) dan perangkat keras (Hardware).

3. Perancangan Aplikasi

Tahap ini adalah pembuatan aplikasi yang sesuai dengan kebutuhan dan keinginan user. Perancangan aplikasi menggunakan tools Unified Modeling Language (UML). UML merupakan salah satu standar bahasa visual yang digunakan untuk mengidentifikasi kebutuhan, membuat analisis dan desain, serta menggambarkan arsitektur dalam pemrograman berorientasi objek [9]. Penelitian ini menggunakan beberapa diagram diantaranya usecase diagram yang menggambarkan hubungan actor dan usecase dalam berinteraksi ke sistem dan activity diagram yang menggambarkan rangkaian aktifitas aktor terhadap sistem.

Pembuatan aplikasi menggunakan sistem operasi Android yaitu sistem operasi untuk perangkat mobile berbasis linux. Android menyediakan platform terbuka bagi para pengembang untuk menciptakan aplikasi. Android merupakan sistem operasi yang menghidupkan lebih dari satu miliar smartphone dan tablet [10]. Perangkat lunak yang digunakan dalam membuat game setatak adalah Unity. Setelah bahan dikumpulkan, dilakukan pengolahan menggunakan engine Unity. Aplikasi unity adalah sebuah software pengolah gambar, suara, grafik, input, dan lainlain yang bertujuan untuk membuat suatu game, walaupun tidak selamanya digunakan untuk game. [11]. Pembuatan background game karakter, petak setatak, dan logo pada game digunakan Adobe Photoshop CS5.

4. Implementasi Metode

Tahap ini dilakukan implementasi metode FSM. FSM merupakan sebuah mesin abstrak yang berfungsi untuk mendefinisikan sekumpulan kondisi yang menentukan kapan suatu state harus berubah. Setiap state yang sedang dijalankan tersebut menentukan perilaku yang terjadi pada objek yang bersangkutan [2].

Secara formal FSM dinyatakan oleh 5 tupel atau $\mathrm{M}=\left(\mathrm{Q}, \sum, \delta, \mathrm{S}, \mathrm{F}\right)$, yaitu :

$\mathrm{Q}=$ himpunan state $/$ kedudukan

$\sum=$ himpunan simbol input/masukan/abjad

$\delta=$ fungsi transisi

$\mathrm{S}=$ state $\mathrm{awal} /$ kedudukan awal (initial state), $\mathrm{S} \mathrm{Q}$

$\mathrm{F}=$ himpunan state akhir, F Q 


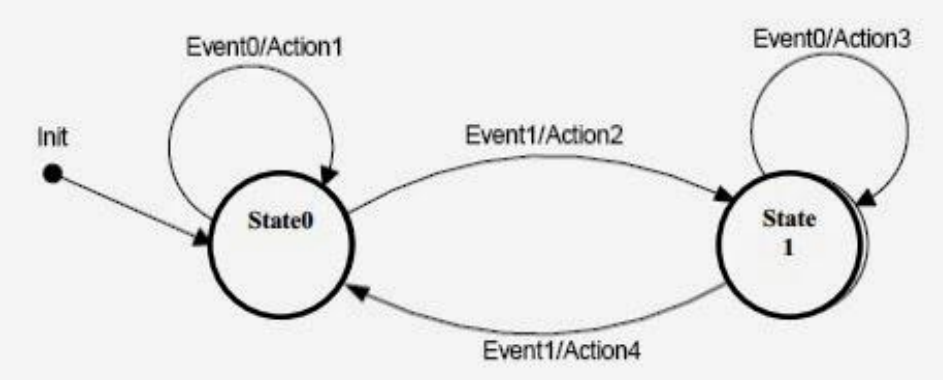

Gambar 3. Skema Finite State Machine

Gambar 3. Memperlihatkan proses diagram state metode FSM dengan dua buah state (State0, State1) dan dua buah input (Event0, Event1) serta empat buah aksi output yang berbeda (Action1, Action2, Action3, Action4). Terlihat pada gambar, ketika sistem mulai dihidupkan, sistem akan bertransisi menuju State0, pada keadaan ini sistem akan menghasilkan Action1 jika terjadi masukan EventO, sedangkan jika terjadi Event1 maka Action2 akan dieksekusi, kemudian sistem selanjutnya bertransisi ke keadaan State1 dan seterusnya [12].

5. Pengujian Aplikasi

Pengujian dilakukan dengan menggunakan metode Black Box, yaitu pengujian perangkat lunak dari segi spesifikasi fungsional tapi tidak menguji desain dan kode program. Tujuannya untuk mengetahui apakah fungsi, masukan dan keluaran dari perangkat lunak sudah sesuai dengan spesifikasi yang dibutuhkan [13]. Setelah itu dilakukan uji terhadap game yang dibuat dilakukan kepada anak-anak yang telah berusia sekitar 7-10 tahun. Pengujian dilakukan untuk mengetahui sejauh mana game ini bisa dimainkan, dimengerti dan dipahami oleh anak-anak.

\section{HASIL DAN PEMBAHASAN}

\subsection{Usecase Diagram}

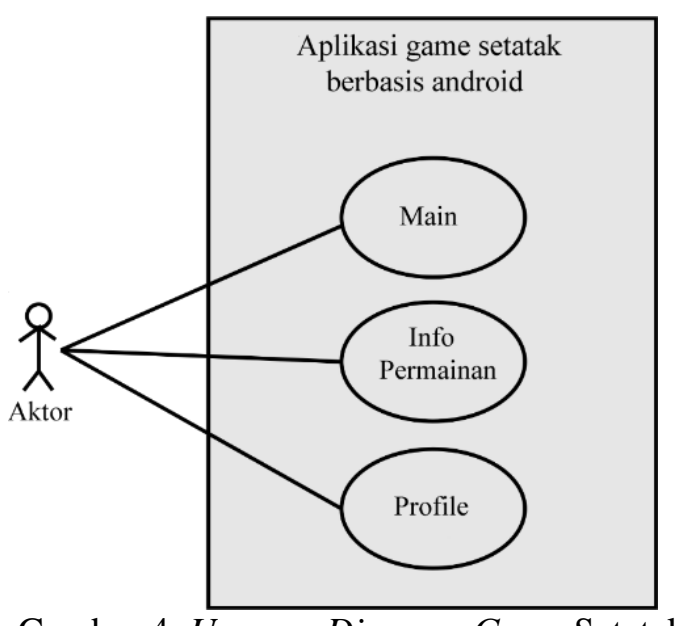

Gambar 4. Usecase Diagram Game Setatak

Usecase diagram game setatak terdapat aktor sebagai player yang akan menggunakan aplikasi yang akan dirancang dan menjalankan fungsi-fungsi yang terdapat pada aplikasi game setatak. Aplikasi game statak ini terdiri tiga menu utama, yaitu main, info permainan dan 
profile. Memulai permainan, aktor memilih menu main. Menu info permainan menyajikan informasi tentang permainan, informasi tentang setatak dan cara permainannya. Menu profile menyajikan informasi tentang aplikasi.

\subsection{Activity Diagram}

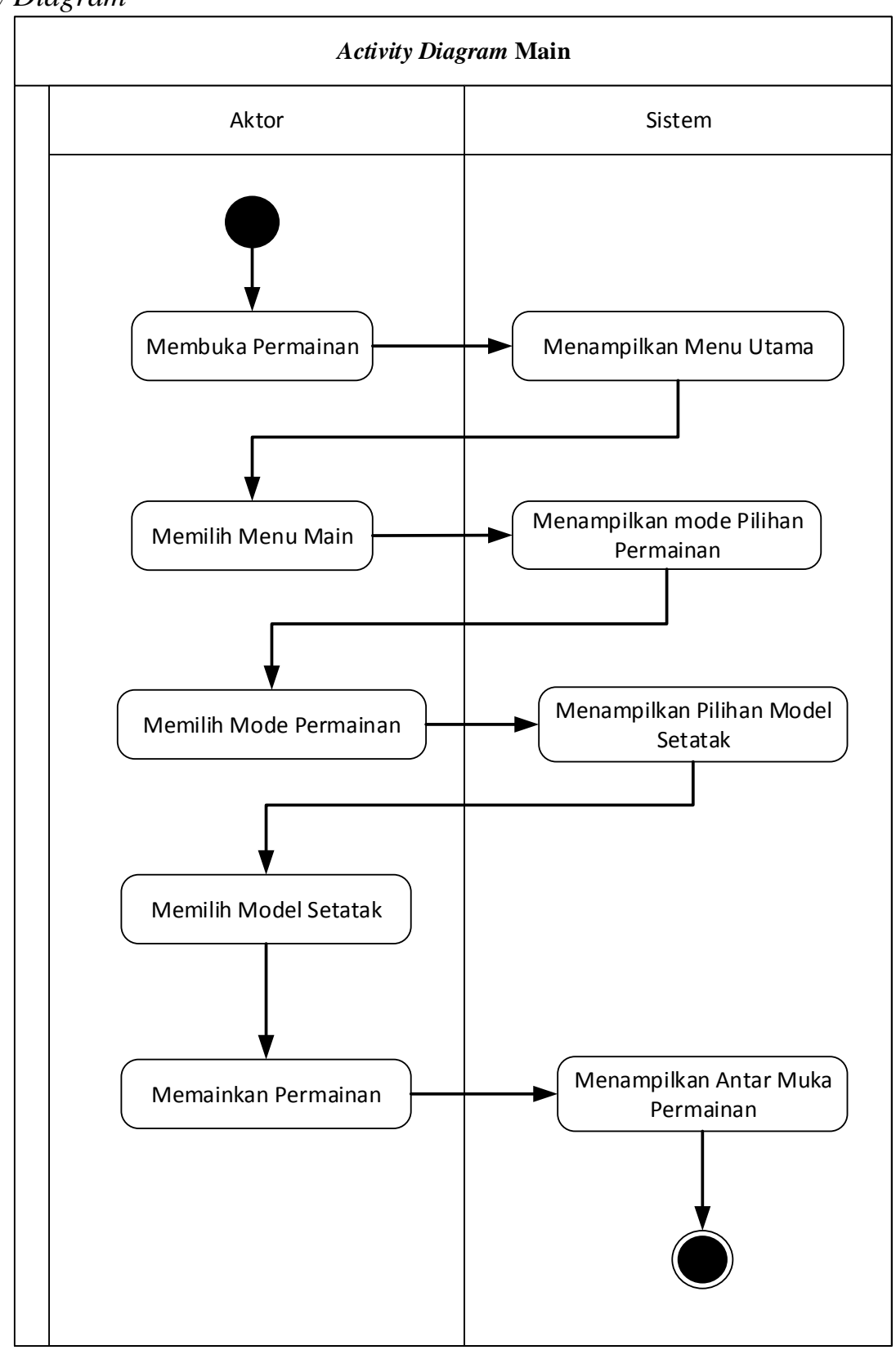

Gambar 5. Activity Diagram Main

Activity diagram pada gambar 5 diatas menjelaskan alur user atau aktor akan memulai memainkan game setatak. Pemain membuka aplikasi, lalu meklik tombol main. Jika terhubung ke dalam game berhasil, akan dilanjutkan menuju pemilihan mode permainan dan setelah pemain memilih mode permainan, dilanjutkan lagi dengan mode pemilihan model setatak. Setelah dipilih maka pemain masuk ke dalam arena permainan game setatak. Pemain akan 
bermain game setatak sesuai dengan petunjuk gamenya. Apabila koneksi pada game gagal atau tidak bisa dilanjutkan maka kembali ke semula pada saat masuk aplikasi.

\subsection{Flowchart}

Flowchart adalah diagram simbol yang menunjukkan arus data dan tahapan operasi dalam sebuah sistem, atau bagan alir yang menunjukkan alur kerja sistem secara keseluruhan dan menjelaskan urutan dari prosedur-prosedur yang ada di dalam sistem [14].

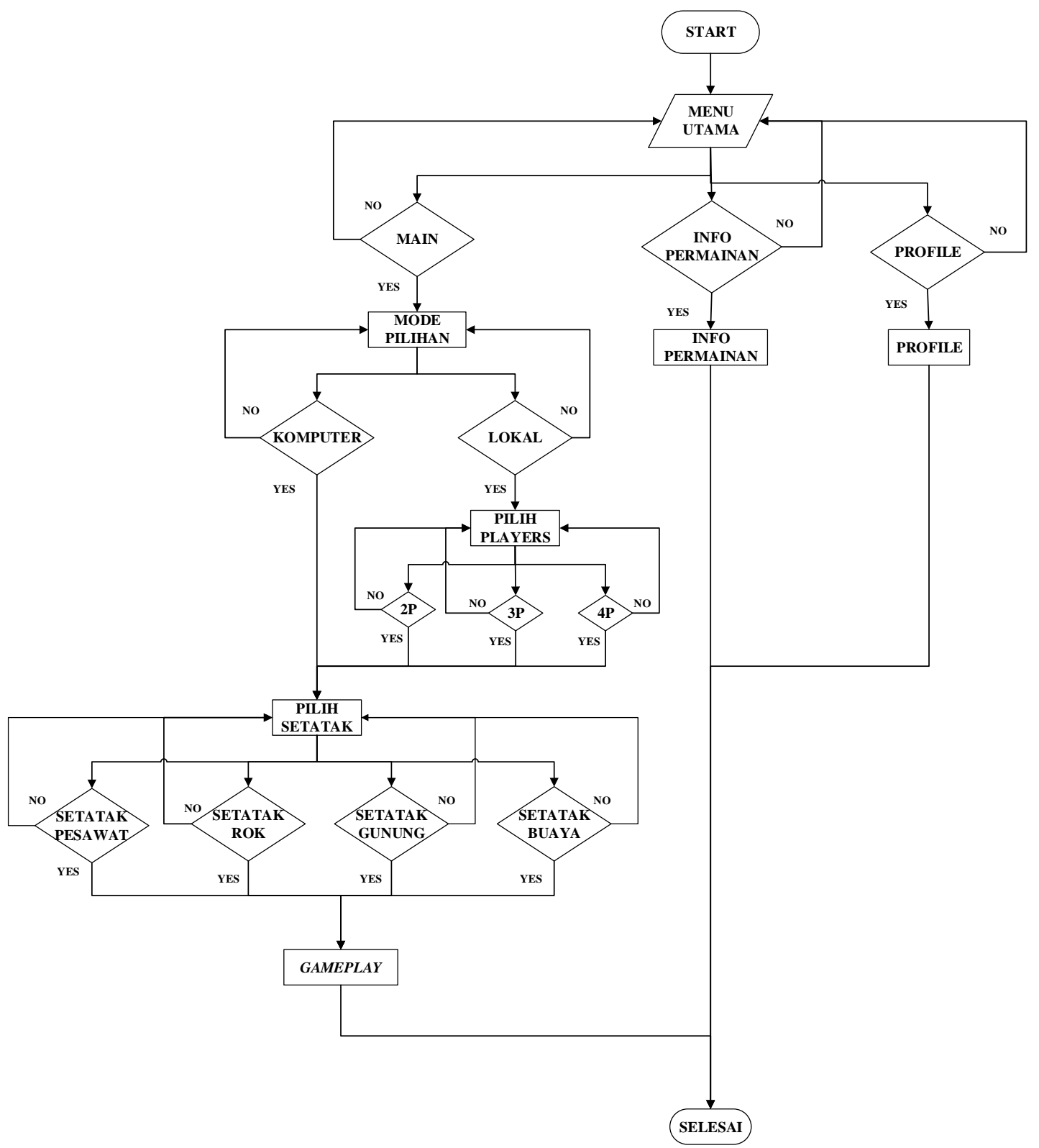

Gambar 6. Flowchart Game Setatak

Berikut keterangan yang menjelaskan gambar 6:

1. Pada menu utama terdapat 3 pilihan

2. Pada pilihan kondisi pertama yaitu bermain, akan menampilkan mode pilihan permainan

3. Pada mode pilihan permainan, akan menampilkan kondisi mode pilihan permainan komputer atau lokal. Kondisi mode pilihan dengan komputer akan menampilkan pilihan 
model setatak. Kondisi mode pilihan mode permainan lokal akan menampilkan menu pilih players

4. Pada tampilan menu pilih players, akan menampilkan kondisi pilihan $2 \mathrm{p}$ ( 2 player $), 3 \mathrm{p}$ ( 3 player), dan $4 \mathrm{p}$ (4 player). Setelah kondisi pilih player terpenuhi, akan menampilkan pilihan model setatak

5. Pada tampilan menu pilih setatak, akan menampilkan kondisi pilihan model setatak pesawat, setatak rok, setatak gunung, setatak buaya. Setelah kondisi pilih setatak terpenuhi, akan menampilkan area permainan atau gameplay

6. Pada pilihan kondisi kedua yaitu info permainan ,akan menampilkan info permainan setatak

7. Pada pilihan kondisi ketiga yaitu profile, akan menampilkan informasi permbuat game setatak.

\subsection{Penerapan Metode Finite State Machine}

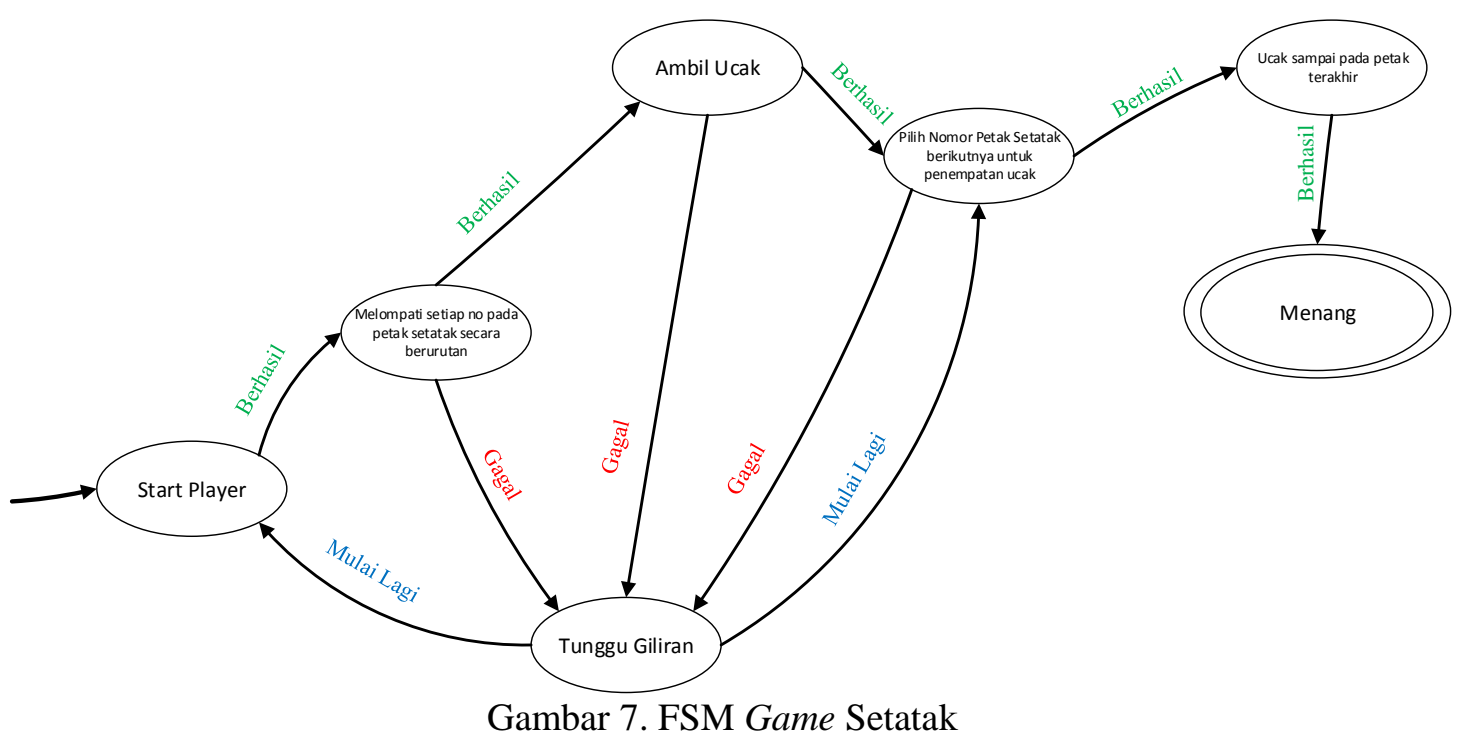

Game setatak diimplementasikan kecerdasan buatan dengan metode FSM. Konsep kerja metode FSM pada game ini adalah untuk mengatur perilaku sistem. Pada saat permainan game, user atau player yang bermain akan melompati setiap petak setatak yang ada, dengan cara melompat dengan menggunakan satu kaki atau dua kaki tergantung pijakannya. Kemudian apabila player berhasil melompati setiap petak-petak setatak, maka player bisa mengambil ucaknya untuk dilemparkan ke petak setatak berikutnya. Ucak yang berhasil sampai pada petak terakhir, dan player yang berhasil mengambil kembali ucaknya pada petak terakhir, maka player tersebut menang. dan sebaliknya apabila player gagal, maka player harus menunggu gilirannya hingga player yang lain gagal. 


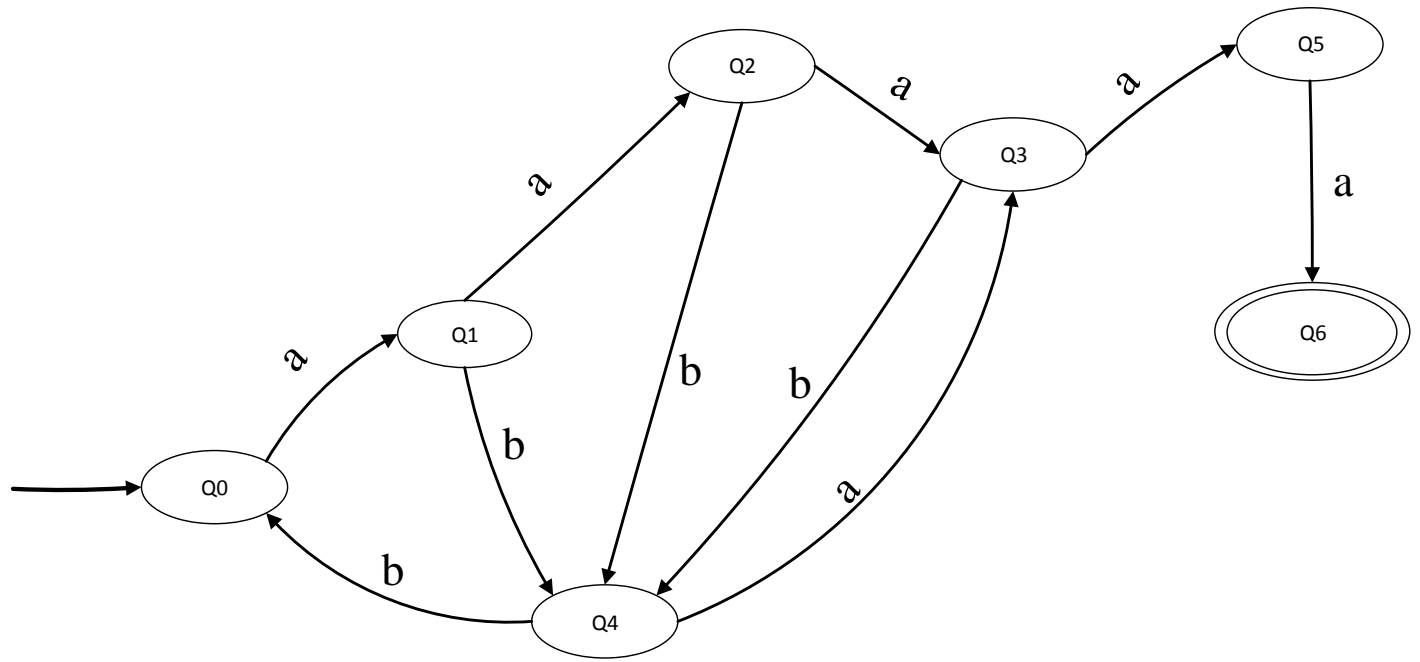

Gambar 8. FSM yang Digunakan DFA pada Game Setatak

Konfigurasi dari Deterministic Finite Automata (DFA) dapat dinyatakan sebagai berikut: $\mathrm{M}=\left(\mathrm{Q}, \sum, \delta, \mathrm{S}, \mathrm{F}\right)$, yaitu :

$\mathrm{Q}=\{\mathrm{Q} 0, \mathrm{Q} 1, \mathrm{Q} 2, \mathrm{Q} 3, \mathrm{Q} 4, \mathrm{Q} 5, \mathrm{Q} 6\}$

$\sum=\{\mathrm{a}, \mathrm{b}\}$

$\mathrm{S}=\mathrm{Q} 0$

$\mathrm{F}=\{\mathrm{Q} 6\}$

Tabel 1. Transisi Game Setatak

Maka :

\begin{tabular}{|l|l|l|}
\hline$\delta$ & $\mathrm{a}$ & $\mathrm{b}$ \\
\hline $\mathrm{Q} 0$ & $\mathrm{Q} 1$ & - \\
\hline $\mathrm{Q} 1$ & $\mathrm{Q} 2$ & $\mathrm{Q} 4$ \\
\hline $\mathrm{Q} 2$ & $\mathrm{Q} 3$ & $\mathrm{Q} 4$ \\
\hline $\mathrm{Q} 3$ & $\mathrm{Q} 5$ & $\mathrm{Q} 4$ \\
\hline Q4 & Q3 & $\mathrm{Q} 0$ \\
\hline Q5 & Q6 & - \\
\hline Q6 & - & - \\
\hline
\end{tabular}

$\delta(\mathrm{Q} 0, \mathrm{a})=\mathrm{Q} 1$

$\delta(\mathrm{Q} 0, \mathrm{~b})=-$

$\delta(\mathrm{Q} 1, \mathrm{a})=\mathrm{Q} 2$

$\delta(\mathrm{Q} 1, \mathrm{~b})=\mathrm{Q} 4$

$\delta(\mathrm{Q} 2, \mathrm{a})=\mathrm{Q} 3$

$\delta(\mathrm{Q} 2, \mathrm{~b})=\mathrm{Q} 4$

$\delta(\mathrm{Q} 3, \mathrm{a})=\mathrm{Q} 5$

$\delta(\mathrm{Q} 3, \mathrm{~b})=\mathrm{Q} 4$

$\delta(\mathrm{Q} 4, \mathrm{a})=\mathrm{Q} 3$

$\delta(\mathrm{Q} 4, \mathrm{~b})=\mathrm{Q} 0$

$\delta(\mathrm{Q} 5, \mathrm{a})=\mathrm{Q} 6$

$\delta(\mathrm{Q} 5, \mathrm{~b})=-$

$\delta(\mathrm{Q} 6, \mathrm{a})=-$

$\delta(\mathrm{Q} 6, \mathrm{~b})=-$

Dari state Q0 jika mendapatkan input 'a' berpindah ke state Q1, dinyatakan : $\delta(\mathrm{Q} 0, \mathrm{a})=$ Q1, Sehingga disebut deterministic (pasti arahnya). Suatu string dapat diterima oleh DFA jika terdapat suatu urutan transisi sehubungan dengan input string tersebut dari state awal (Q0) menuju ke state akhir (Q6). 


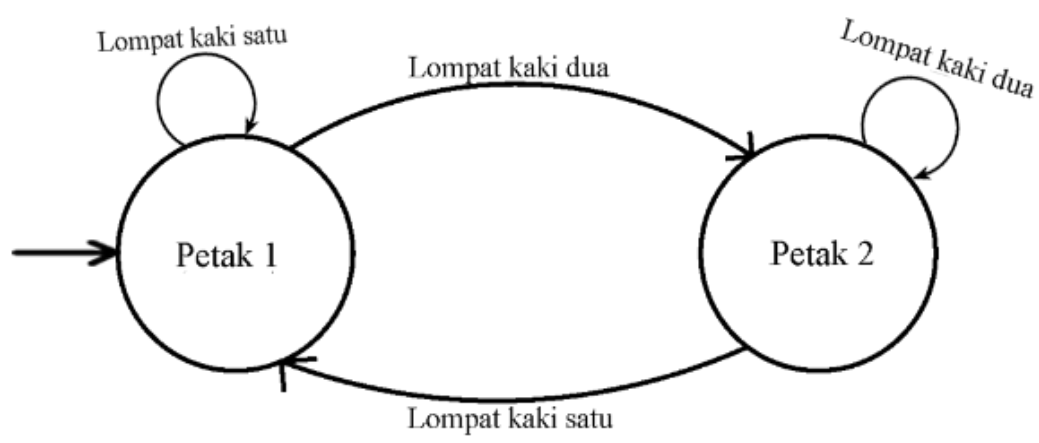

Gambar 9. FSM pada Pergerakan Player Melompat

Pada gambar 9 diatas menjelaskan kondisi lompatan diberikan input lompat kaki dua, player akan melompat kaki dua pada petak setatak yang pijakannya dua, apabila diberikan input lompat kaki satu, player akan melompat pada petak setatak yang pijakannya satu.

Defini dalam bentuk 5 tupel :

Lompat kaki dua $=$

$\mathrm{M}=\left(\mathrm{Q}, \sum, \delta, \mathrm{S}, \mathrm{F}\right)$, yaitu :

$\mathrm{Q}=\{$ Petak1, Petak2 $\}$

$\sum=\{$ LompatKaki1, LompatKaki2 $\}$

$\mathrm{S}=$ Petak 1

$\mathrm{F}=\{$ Petak 2$\}$

Tabel 2. Transisi lompatan pada game setatak

\begin{tabular}{|l|l|l|}
\hline$\delta$ & Lompat Kaki1 & LompatKaki2 \\
\hline Petak1 & Petak1 & Petak2 \\
\hline Petak2 & Petak1 & Petak2 \\
\hline
\end{tabular}

Maka

$\delta($ Petak1, LompatKaki1 $)=$ Petak 1

$\delta($ Petak1, LompatKaki2 $)=$ Petak 2

$\delta($ Petak2, LompatKaki 1$)=$ Petak 1

$\delta($ Petak2, LompatKaki2 $)=$ Petak

\subsection{Antarmuka Aplikasi}

a. Tampilan Menu Utama Aplikasi

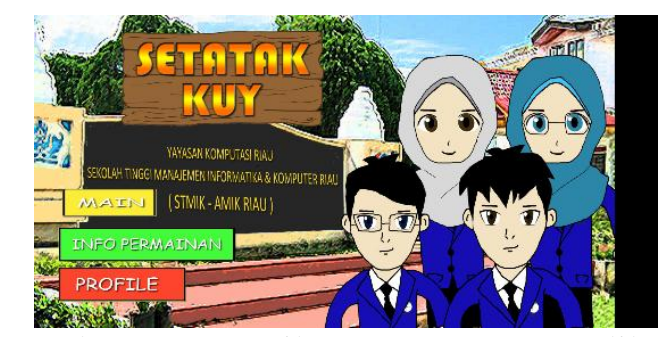

Gambar 12. Tampilan Menu Utama Aplikasi

Gambar 12 diatas, merupakan tampilan awal pada game setatak, dimana terdapat background judul game, tombol main, tombol info permainan, dan tombol profile. 
b. Tampilan Menu Pilihan Players dan Pilihan Setatak

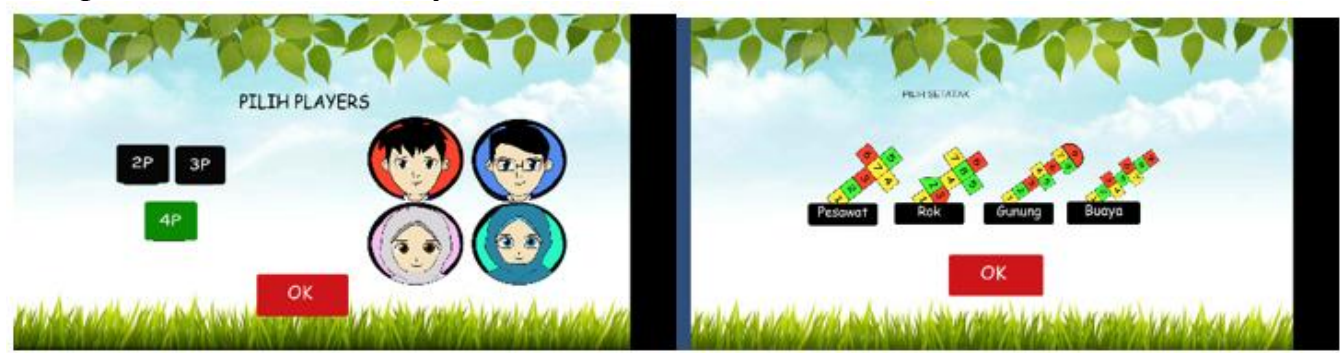

Gambar 13. Tampilan Pilih Players dan Pilihan Setatak

Pada gambar 13 merupakan tampilan pilih players. Pilih players berfungsi untuk menentukan banyaknya player yang ingin dimainkan dalam arena permainan setatak. Setelah dipilih lalu muncul tampilan pilih setatak, user dapat memilih arena permainan atau model setatak, yang terdiri dari empat model setatak, yaitu: setatak pesawat, setatak rok, setatak gunung, dan setatak buaya.

c. Tampilan Setatak Pesawat

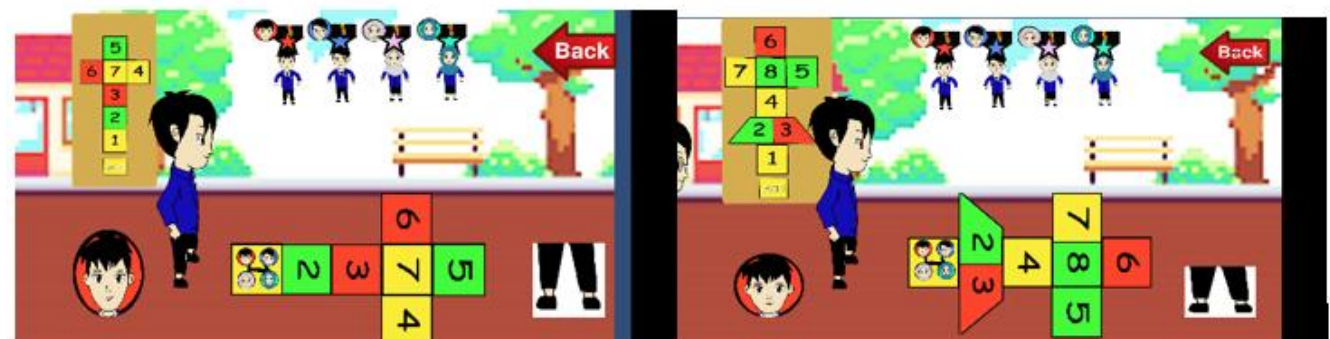

Gambar 14. Setatak Pesawat dan Setatak Rok

Gambar 14 merupakan tampilan setatak pada arena atau model permainan setatak pesawat dan setatak rok. Pemain bermain dengan lebih dari 1 aktor/player. dimana player pertama akan mulai terlebih dahulu, dengan cara melewati setiap petak setatak model pesawat atau setatak rok. Setatak pesawat memiliki 7 petak setatak. Player diharuskan bisa melewati semua petak setatak pesawat, dan ucak player harus bisa berada pada petak terakhir yaitu petak nomor 7 pada setatak pesawat. Begitu juga dengan setatak rok memiliki 8 petak setatak. Player diharuskan bisa melewati semua petak setatak rok, dan ucak player harus bisa berada pada petak terakhir yaitu petak nomor 8 pada setatak rok. Pada setatak gunung dan setatak buaya, Player diharuskan bisa melewati petak terakhir yaitu sampai petak nomor 9 pada masing-masing setatak.

d. Tampilan Spin Setatak

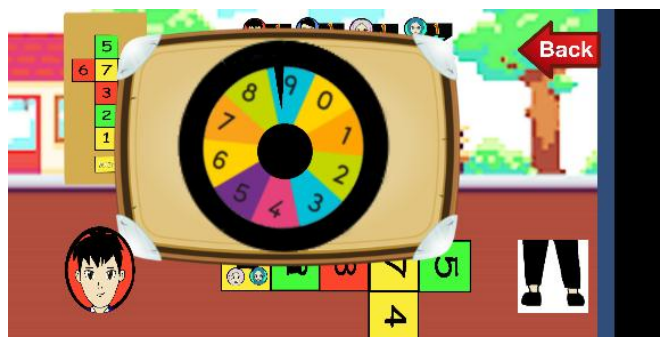

Gambar 15. Spin Setatak

Gambar 15 diatas merupakan spin setatak berfungsi untuk menempatkan ucak setatak player pada nomor petak setatak berikutnya. 
e. Tampilan Pergerakan player melewati arena petak setatak

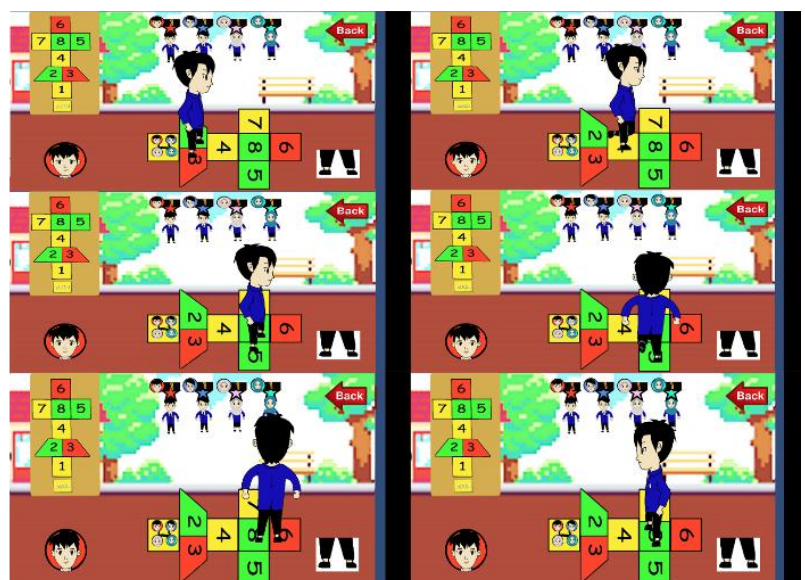

Gambar 16. Pergerakan Player Melewati Arena Petak Setatak Rok

Pergerakan player pada arena permainan setatak rok, diawali pada petak 2 dan 3 dengan player menggunakan kaki dua, untuk petak 4 player menggunakan kaki satu. Pada petak 5 player harus menggunakan kaki dua pada petak 5 dan 8 kemudian kaki satu pada petak 5. Pada petak 6 player harus menggunakan kaki dua pada petak 6 dan 8 kemudian kaki satu pada petak 6. Pada petak 7 player harus menggunakan kaki dua pada petak 7 dan 8 kemudian kaki satu pada petak 7. Pada petak 8 karakter akan otomatis kaki dua. Pada arena permainan setatak rok, player harus melewati 8 petak setatak. Demikian juga dengan model setatak lainnya, pergerakan kaki menyesuaikan dan harus melewati semua petak dari model setataknya

\subsection{Pengujian Game Setatak pada Anak-anak}

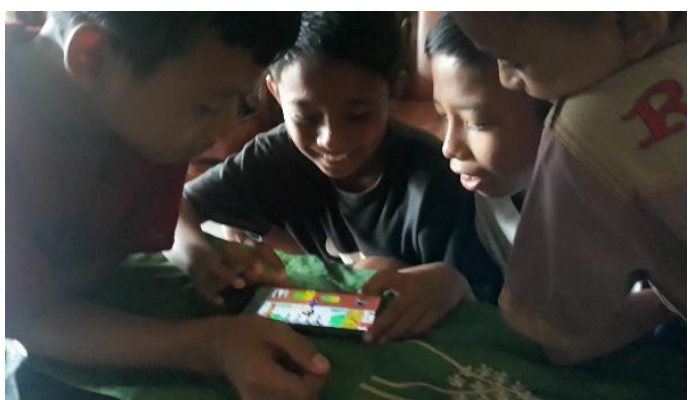

Gambar 17. Implementasi Game Setatak pada Anak-anak

Pada tahap ini, diundang beberapa anak-anak untuk mencoba permainan game setatak yang telah dibuat, gunanya untuk mengetahui pemahaman anak-anak terhadap aplikasi game, cara pemakaian dan keberhasilan dari memainkan game ini.

\section{KESIMPULAN}

Kesimpulan penelitian ini adalah aplikasi permainan game setatak sudah berhasil dibuat dalam bentuk game 2 dimensi berbasis android dengan metode finite state machine, serta memiliki empat model setatak, yang terdiri dari: setatak pesawat, setatak rok, setatak gunung, dan setatak buaya. Metode finite state machine telah mampu mengatur perilaku sistem, yaitu perpindahan kaki pemain dari satu petak ke petak yang lainnya selama game berlangsung.

Agustin, et., al [Implementasi Metode Finite State Machine pada Permainan Tradisional Setatak Berbasis Android] 
Aplikasi game setatak ini menjadi alternatif untuk menjaga dan melestarikan salah satu permaian tradisional kepada anak-anak. Hasil pengujian menunjukkan bahwa game setatak dapat menambah pengetahuan permainan tradisional setatak, dan disukai serta diminati oleh anak-anak.

\section{SARAN}

Saran yang diberikan agar penelitan ini lebih baik kedepannya antara lain:

1. Harapannya dengan adanya penelitian ini, peneliti selanjutnya dapat melakukan perbandingan dengan menggunakan metode pembuatan game lainnya.

2. Aplikasi yang dibuat masih dalam bentuk game dua dimensi, untuk penelitian berikutnya bisa dalam bentuk tigs dimensi.

\section{DAFTAR PUSTAKA}

[1] "Permainan Tradisional - https://www.cnnindonesia.com/hiburan/20180817120306-241323001/permainan-tradisional-puncak-dari-segala-kebudayaan.”.

[2] D. S. Hormansyah, A. R. T. H. Ririd, and D. T. Pribadi. 2018, "Implementasi FSM (Finite State Machine) pada Game Perjuangan Pangeran Diponegoro," J. Inform. Polinema, Vol. 4, No. 4, p. 290, doi: 10.33795/jip.v4i4.222.

[3] “Permainan Tradusional Setatak- https://budaya-indonesia.org/Setatak.” .

[4] M. F. Rahadian, A. Suyatno, and S. Maharani. 2016, "Penerapan Metode Finite State Machine pada Game 'The Relationship,' Inform. Mulawarman J. Ilm. Ilmu Komput., Vol. 11, No. 1, p. 14, doi: 10.30872/jim.v11i1.198.

[5] F. Marzian and M. Qamal. 2017, "Game RPG ' The Royal Sword'Berbasis Desktop Dengan Menggunakan Metode Finite State Machine ( FSM ), ” Sist. Inf., pp. 61-96.

[6] D. M. Anugraha, I. Agustina, and F. Fauziah. 2018, "Game Edukasi Berbasis Kinect Untuk Anak Berkebutuhan Khusus (Autis) Dengan Metode Finite State Machine," JOINTECS (Journal Inf. Technol. Comput. Sci., Vol. 3, No. 1, doi: 10.31328/jointecs.v3i1.501.

[7] S. R. Ramadhan Haris Febriyanto, Sampe Hotlan Sitorus. 2019, "Game Edukasi Pengenalan Budaya dan Wisata Kalimantan Barat Menggunakan Metdoe Finite State Machine Berbasis Android," Coding J. Komput. dan Apl., Vol. 07, No. 1, pp. 108-119,

[8] E. W. Hidayat, A. N. Rachman, and M. F. Azim. 2019, "Penerapan Finite State Machine pada Battle Game Berbasis Augmented Reality," J. Edukasi dan Penelit. Inform., Vol. 5, No. 1, p. 54, doi: 10.26418/jp.v5i1.29848.

[9] $\quad$ R. S. dan M. S. A. 2013, "Rekayasa Peangkat Lunak Terstruktur dan Berorientasi Objek Edisi 2.” Informatika, Bandung, pp. 146-167.

[10] Y. Efendi. 2018, "Rancangan Aplikasi Game Edukasi Berbasis Mobile Menggunakan App Inventor," J. Intra-Tech, Vol. 2, No. 1, p. 41. 
[11] A. Nugroho and B. A. Pramono. 2017, “Aplikasi Mobile Augmented Reality Berbasis Vuforia dan Unity pada Pengenalan Objek 3D Dengan Studi Kasus Gedung M Universitas Semarang," J. Transform., Vol. 14, No. 2, p. 86, doi: 10.26623/transformatika.v14i2.442.

[12] E. Yulsilviana and H. Ekawati. 2019, "Penerapan Metode Finite State Machine (FSM) Pada Game Agent Legenda Anak Borneo,” Sebatik, Vol. 23, No. 1, pp. 116-123.

[13] W. N. Cholifah, Y. Yulianingsih, and S. M. Sagita. 2018, "Pengujian Black Box Testing pada Aplikasi Action \& Strategy Berbasis Android Dengan Teknologi Phonegap," STRING (Satuan Tulisan Ris. dan Inov. Teknol., Vol. 3, No. 2, p. 206, doi: 10.30998/string.v3i2.3048.

[14] S. Ratumurun. 2015, "Sistem Informasi Akuntansi Permintaan Barang dari Gudang pada PT. Mauwasa Sejahtera Ambon,” Vol. IX, No. 1. 